\title{
Isolation of Monoclonal Antibodies from Zika Virus-Infected Patient Samples
}

\author{
Qihui Wang and Jinghua Yan
}

\begin{abstract}
The combination of sorting antigen-specific memory B cells with determining immunoglobulin (Ig) genes at the single-cell level enables the isolation of monoclonal antibodies (mAbs) in individuals. This method requires a small amount of blood (usually $10 \mathrm{~mL}$ ) and is rapid (less than 2 weeks to isolate antigen-specific $\mathrm{mAbs}$ ). Due to the application of antigens as the bait to capture the specific memory B cells, the majority of isolated $\mathrm{mAbs}$ are true binders to the antigen, which increases the isolation efficiency. Here, applying this approach, we describe the characterization of $\mathrm{mAbs}$ against Zika virus from a convalescent patient sample. From $10 \mathrm{~mL}$ whole blood, we sorted 33 Zika envelope (E) protein-interacting single memory B cells. The Ig genes from 15 cells were determined, and $13 \mathrm{mAbs}$ were found that bind to Zika E protein with varied binding affinities.
\end{abstract}

Key words Zika virus, Memory B cells, Monoclonal antibodies, Therapeutic antibodies, Convalescent patients

\section{Introduction}

Zika virus has caused global concern due to the accumulating evidence suggesting that infection is associated with microcephaly and neurological complications, such as Guillain-Barré syndrome [1-4]. However, there are currently no approved antivirals against Zika infection [5]. Administration of polyclonal or purified neutralizing monoclonal antibodies (mAbs) to pregnant mice helps to clear the virus and alleviates the neurological disorders in their fetuses $[6,7]$, providing proof of concept that neutralizing mAbs can be used to treat Zika virus infections. Currently, multiple strategies have been reported to generate human neutralizing mAbs against Zika infection, including sequencing antigen-specific memory B cells $[8,9]$ or generating Epstein-Barr virus-immortalized memory B cells from Zika patient samples [10], and identifying functional mAbs from phage display naïve antibody libraries 
[11]. In addition, murine mAbs against Zika virus have also been reported [12].

Here, we introduce a method to apply Zika envelope (E) glycoproteins, which play pivotal roles in virus entry and contain important neutralizing epitopes, to sort single memory B cells from a convalescent Zika patient. Subsequently, the immunoglobulin $(\mathrm{Ig})$ genes encoded by the sorted cells were determined at the single-cell level. The approach to determine the Ig genes from single cells was first reported by Tiller et al. [13]. Later, Scheid et al. modified this approach to sequence single gpl40-binding memory B cells, which were isolated from human immunodeficiency virus (HIV) patients [14]. Then the mAbs against human papillomavirus (HPV) or respiratory syncytial virus (RSV) were isolated from immunized or naturally infected human donors, respectively $[15,16]$. During the epidemic of Zika virus, we and other groups also applied this strategy to isolate mAbs targeting Zika virus from Zika patients [8,9].

From $10 \mathrm{~mL}$ whole blood, we were able to pair $15 \mathrm{mAbs}$ from 33 collected single cells. As detected by surface plasmon resonance (SPR), 13 of the mAbs were true binders to Zika E protein [8].

Although the protocol depicted in this chapter focuses on the isolation of Zika mAbs from a Zika convalescent patient, it could also be expanded to other viruses, and we recently reported the isolation of human neutralizing mAbs against Rift Valley fever virus (RVFV) from a convalescent RVF patient, applying the same strategy [17].

\section{Materials}

\subsection{Isolation of Peripheral Blood Mononuclear Cells (PBMCs)}

1. $10 \mathrm{~mL}$ Plastic $\mathrm{K}_{2}$ EDTA Tubes.

2. Density gradient medium.

3. PBS $(10 \times$ stock): dissolve $80 \mathrm{~g}$ of $\mathrm{NaCl}, 2 \mathrm{~g}$ of $\mathrm{KCl}, 14.4 \mathrm{~g}$ of $\mathrm{Na}_{2} \mathrm{HPO}_{4}$, and $2.4 \mathrm{~g}$ of $\mathrm{KH}_{2} \mathrm{PO}_{4}$ in $800 \mathrm{~mL}$ of ddH $\mathrm{H}_{2} \mathrm{O}$. Adjust the $\mathrm{pH}$ to 7.4 with $\mathrm{HCl}$ and then add $\mathrm{ddH}_{2} \mathrm{O}$ to $1 \mathrm{~L}$. Dispense the solution into aliquots and sterilize them by autoclaving for $15 \mathrm{~min}$ at $121^{\circ} \mathrm{C}$ or by filter sterilization. Store PBS at room temperature.

4. $50 \mathrm{~mL}$ centrifuge tubes.

5. $15 \mathrm{~mL}$ centrifuge tubes.

6. FACS buffer: PBS with $1 \%$ fetal bovine serum (FBS) filtered through a $0.22 \mu \mathrm{m}$ membrane for sterilization.

7. Freezing medium: FBS with 10\% DMSO.

8. Freezing containers.

9. $2 \mathrm{~mL}$ freezing tubes.

10. Automated cell counter and adapted cell counting chamber. 


\section{Table 1}

The staining master mix for isolation of antigen-specific memory B cells

\begin{tabular}{lc}
\hline Antigen & Amount $(\mu \mathrm{L})$ \\
\hline Human CD3 & 10 \\
\hline Human CD16 & 10 \\
\hline Human CD235a & 10 \\
\hline Human CD19 & 10 \\
\hline Human CD27 & 4 \\
\hline Human CD38 & 10 \\
\hline Human IgG & 10 \\
\hline His & 20 \\
\hline FACS buffer & 16 \\
\hline Total volume & 100 \\
\hline
\end{tabular}

\subsection{Cell Sorting}

1. Antibodies: anti-human CD3/PE-Cy ${ }^{\mathbb{R}} 5$ (BD Biosciences), antihuman $\mathrm{CD} 16 / \mathrm{PE}-\mathrm{Cy}^{\circledR} 5$ (BD Biosciences), anti-human CD235a/PE-Cy ${ }^{\circledR} 5$ (BD Biosciences), anti-human CD19/ APC-Cy ${ }^{\circledR} 7$ (BD Biosciences), anti-human CD27/Pacific Blue ${ }^{\circledR}$ (BioLegend), anti-human CD38/APC (BD Biosciences), antihuman IgG/FITC (BD Biosciences), and anti-His/PE (Miltenyi Biotec).

2. Prepare a staining master $\operatorname{mix}$ in a $1.5 \mathrm{~mL}$ microcentrifuge tube. The antibody cocktail is listed in Table 1 .

Centrifuge the master mix at $15,000 \times g$ at $4{ }^{\circ} \mathrm{C}$ for $1 \mathrm{~min}$. Store staining master mix at $4{ }^{\circ} \mathrm{C}$ in the dark before use.

3. Antigen: Purified Zika E protein or MERS-RBD, both of which contain a $6 \times$ His tag at their C-terminus. Adjust the protein concentration to $1 \mathrm{mg} / \mathrm{mL}$.

4. FACS tubes.

5. Compensation beads.

6. Cell sorter.

7. $37^{\circ} \mathrm{C}$ water bath.

8. $70 \%$ ethanol.

2.3 Ig Gene Amplification
1. Reverse transcription (RT)-PCR synthesis system for the firststrand cDNA.

2. 96-Well PCR Plates.

3. PCR Plate Seal.

4. DEPC-treated $\mathrm{ddH}_{2} \mathrm{O}$. 


\subsection{Primers Used for Ig Gene Amplification (See Notes 3 and 4)}

5. DNA polymerase (for single-cell PCR).

6. $10 \times$ TAE buffer.

7. Agarose.

8. Ethidium bromide $(\mathrm{EtBr})$ at $10 \mathrm{mg} / \mathrm{mL}$.

9. $1.2 \%$ agarose gel: dissolve $0.36 \mathrm{~g}$ of agarose in $200 \mathrm{~mL}$ of $1 \times$ TAE buffer. Heat the solution to boiling in the microwave until no particles are observed. Add $6 \mu \mathrm{L}$ of EtBr to the dissolved agarose and mix. Cool the solution to $60{ }^{\circ} \mathrm{C}$ prior to casting. Place spacers in the slots of a gel tank and pour the agarose solution into the area between the spacers. Then place a gel comb in position indicated by slots in the tank. Leave to set for approximately $30 \mathrm{~min}$. Before using, remove the spacers and the comb from the gel (see Notes 1 and 2).

10. Gel Extraction Micro Kit for micro samples.

11. Gel electrophoresis instrument.

1. Primers for reverse transcription (RT) are listed in Table 2.

2. Primers for the first round PCR (PCRa) to amplify $\mathrm{V}_{\mathrm{H}}$ are listed in Table 3.

3. Primers for the PCRa to amplify $\mathrm{V}_{\mathrm{K}}$ are listed in Table 4.

4. Primers for the PCRa to amplify $\mathrm{V}_{\lambda}$ are listed in Table 5.

5. Primers for the second round PCR (PCRb) to amplify $\mathrm{V}_{\mathrm{H}}$ are listed in Table 6.

6. Primers for the PCRb to amplify $\mathrm{V}_{\mathrm{K}}$ are listed in Table 7.

7. Primers for the PCRb to amplify $\mathrm{V}_{\lambda}$ are listed in Table 8 .

8. Other primers used in this study are listed in Table 9.

\section{Table 2}

Primers for RT reaction

\begin{tabular}{ll}
\hline RT primer & $\mathbf{5}^{\prime} \mathbf{- 3}^{\prime}$ sequence \\
\hline IgM-RT & ATG GAG TCG GGA AGG AAG TC \\
\hline IgD-RT & TCA CGG ACG TTG GGT GGT A \\
\hline IgE-RT & TCA CGG AGG TGG CAT TGG A \\
\hline IgAl-RT & CAG GCG ATG ACC ACG TTC C \\
\hline IgA2-RT & CAT GCG ACG ACC ACG TTC C \\
\hline IgG-RT & AGG TGT GCA CGC CGC TGG TC \\
\hline Cא-new RT & GCA GGC ACA CAA CAG AGG CA \\
\hline C $\lambda$-new-ext & AGG CCA CTG TCA CAG CT \\
\hline
\end{tabular}


Table 3

Primers for the PCRa to amplify $\mathbf{V}_{\mathbf{H}}$

\begin{tabular}{ll}
\hline Forward primer & $\mathbf{5}^{\prime}-\mathbf{3}^{\prime}$ sequence \\
\hline $\mathrm{V}_{\mathrm{H}}$ 1-Ext & CCA TGG ACT GGA CCT GGA GG \\
\hline $\mathrm{V}_{\mathrm{H}}$ 2-Ext & ATG GAC ATA CTT TGT TCC A \\
\hline $\mathrm{V}_{\mathrm{H}}$ 3-Ext & CCA TGG AGT TTG GGC TGA GC \\
\hline $\mathrm{V}_{\mathrm{H}} 4$-Ext & ATG AAA CAC CTG TGG TTC TT \\
\hline $\mathrm{V}_{\mathrm{H}}$ 5-Ext & ATG GGG TCA ACC GCC ATC CT \\
\hline $\mathrm{V}_{\mathrm{H}}$ 6-Ext & ATG TCT GTC TCC TTC CTC AT \\
\hline Reverse primer & $\mathbf{5}^{\prime}-\mathbf{3}^{\prime}$ sequence \\
\hline IgG-exta & CGC CTG AGT TCC ACG ACA CC \\
\hline
\end{tabular}

Table 4

Primers for the PCRa to amplify $\mathbf{V}_{\mathrm{\kappa}}$

\begin{tabular}{|c|c|}
\hline Forward primer & $5^{\prime}-3^{\prime}$ sequence \\
\hline $\mathrm{V}_{\mathrm{K}} \mathrm{l} / 2$-Ext & GCT CAG CTC CTG GGG CT \\
\hline $\mathrm{V}_{\mathrm{\kappa}} 3$-Ext & GGA ARC CCC AGC DCA GC \\
\hline $\mathrm{V}_{\mathrm{K}} 4 / 5-\mathrm{Ext}$ & CTS TTS CTY TGG ATC TCT G \\
\hline $\mathrm{V}_{\kappa} 6 / 7-\mathrm{Ext}$ & CTS CTG CTC TGG GYT CC \\
\hline Reverse primer & $5^{\prime}-3^{\prime}$ sequence \\
\hline Ск-ext & GAG GCA GTT CCA GAT TTC AA \\
\hline
\end{tabular}

\section{Table 5}

Primers for the PCRa to amplify $\mathbf{V}_{\lambda}$

\begin{tabular}{ll}
\hline Forward primer & $\mathbf{5}^{\prime} \mathbf{- 3}^{\prime}$ sequence \\
\hline $\mathrm{V}_{\lambda}$ l-Ext & CCT GGG CCC AGT CTG TG \\
\hline $\mathrm{V}_{\lambda}$-Ext & CTC CTC ASY CTC CTC ACT \\
\hline $\mathrm{V}_{\lambda}$-Ext & GGC CTC CTA TGW GCT GAC \\
$\mathrm{V}_{\lambda}$ 31-Ext & GTT CTG TGG TTT CTT CTG AGC TG \\
\hline $\mathrm{V}_{\lambda} 4$ ab-Ext & ACA GGG TCT CTC TCC CAG \\
\hline $\mathrm{V}_{\lambda} 4$ c-Ext & ACA GGT CTC TGT GCT CTG C \\
\hline $\mathrm{V}_{\lambda} 5 / 9-$ Ext & CCC TCT CSC AGS CTG TG \\
\hline $\mathrm{V}_{\lambda}$ 6-Ext & TCT TGG GCC AAT TTT ATG C \\
\hline $\mathrm{V}_{\lambda} 7 / 8$-Ext & ATT CYC AGR CTG TGG TGA C \\
\hline $\mathrm{V}_{\lambda}$ 10-Ext & CAG TGG TCC AGG CAG GG \\
\hline Reverse primer & $\mathbf{5}^{\prime}-\mathbf{3}^{\prime}$ sequence \\
\hline $\mathrm{C}_{\lambda}$-new-ext & AGG CCA CTG TCA CAG CT \\
\hline
\end{tabular}


Table 6

Primers for the PCRb to amplify $\mathbf{V}_{\mathbf{H}}$

\begin{tabular}{|c|c|}
\hline Forward primer & $5^{\prime}-3^{\prime}$ sequence \\
\hline $\mathrm{V}_{\mathrm{H}} \mathrm{l}$-Int tag & $\begin{array}{l}\text { CTGGGTTCCAGGTTCCACTGGTGAC } \\
\text { CAG GTG CAG CTG GTR CAG TCT GGG }\end{array}$ \\
\hline $\mathrm{V}_{\mathrm{H}} 2$-Int tag & $\begin{array}{l}\text { СTGGGTTCCAGGTTCCACTGGTGAC } \\
\text { CAG RGC ACC TTG ARG GAG TCT GGT CC }\end{array}$ \\
\hline $\mathrm{V}_{\mathrm{H}} 3$-Int tag & $\begin{array}{l}\text { CTGGGTTCCAGGTTCCACTGGTGAC } \\
\text { GAG GTK CAG CTG GTG GAG TCT GGG }\end{array}$ \\
\hline $\mathrm{V}_{\mathrm{H}} 4$-Int tag & $\begin{array}{l}\text { СTGGGTTCCAGGTTCCACTGGTGAC } \\
\text { CAG GTG CAG CTG CAG GAG TCG G }\end{array}$ \\
\hline $\mathrm{V}_{\mathrm{H}} 5$-Int tag & $\begin{array}{l}\text { CTGGGTTCCAGGTTCCACTGGTGAC } \\
\text { GAR GTG CAG CTG GTG CAG TCT GGA G }\end{array}$ \\
\hline $\mathrm{V}_{\mathrm{H}} 6$-Int tag & $\begin{array}{l}\text { CTGGGTTCCAGGTTCCACTGGTGAC } \\
\text { CAG GTA CAG CTG CAG CAG TCA GGT CC }\end{array}$ \\
\hline Reverse primer & $5^{\prime}-3^{\prime}$ sequence \\
\hline IgG-extb & $\begin{array}{l}\text { GC TGT GCC CCC AGA GGT } \\
\text { GCT CYT GGA }\end{array}$ \\
\hline
\end{tabular}

Table 7

Primers for the PCRb to amplify $\mathbf{V}_{\kappa}$

\begin{tabular}{|c|c|}
\hline Forward primer & $5^{\prime}-3^{\prime}$ sequence \\
\hline $\mathrm{V}_{\mathrm{K}} \mathrm{l}$-Int tag & CTGGGTTCCAGGTTCCACTGGTGACGAC ATC CAG WTG ACC CAG TCT C \\
\hline $\mathrm{V}_{\mathrm{k}} 2$-Int tag & СTGGGTTCCAGGTTCCACTGGTGACGAT ATT GTG ATG ACC CAG WCT CCA C \\
\hline $\mathrm{V}_{\mathrm{k}} 3$-Int tag & СTGGGTTCCAGGTTCCACTGGTGACGAA ATT GTG TTG ACR CAG TCT CCA \\
\hline $\mathrm{V}_{\mathrm{K}} 4$-Int tag & CTGGGTTCCAGGTTCCACTGGTGACGAC ATC GTG ATG ACC CAG TCT C \\
\hline $\mathrm{V}_{\mathrm{K}} 5$-Int tag & CTGGGTTCCAGGTTCCACTGGTGACGAA ACG ACA CTC ACG CAG TCT C \\
\hline $\mathrm{V}_{\mathrm{k}} 6$-Int tag & СTGGGTTCCAGGTTCCACTGGTGACGAA ATT GTG CTG ACW CAG TCT CCA \\
\hline $\mathrm{V}_{\mathrm{k}} 7$-Int tag & СTGGGTTCCAGGTTCCACTGGTGACGAC ATT GTG CTG ACC CAG TCT \\
\hline Reverse primer & $5^{\prime}-3^{\prime}$ sequence \\
\hline Cא-int & GGG AAG ATG AAG ACA GAT GGT \\
\hline
\end{tabular}

\subsection{Expression} Vector Cloning
1. High-Fidelity DNA Polymerase.

2. Gel Extraction Kit.

3. Universal DNA Purification Kit. Plasmids purification kit.

4. EcoRI.

5. KpnI. 
Table 8

Primers for the PCRb to amplify $\mathbf{V}_{\lambda}$

\begin{tabular}{|c|c|}
\hline Forward primer & $5^{\prime}-3^{\prime}$ sequence \\
\hline $\mathrm{V}_{\lambda} \mathrm{l}$-Int tag & $\begin{array}{l}\text { CTGGGTTCCAGGTTCCACTGGTGAC } \\
\text { CAG TCT GTG YTG ACK CAG CC }\end{array}$ \\
\hline $\mathrm{V}_{\lambda} 2$-Int tag & $\begin{array}{l}\text { CTGGGTTCCAGGTTCCACTGGTGAC } \\
\text { CAG TCT GCC CTG ACT CAG CC }\end{array}$ \\
\hline $\mathrm{V}_{\lambda} 3$-Int tag & $\begin{array}{l}\text { CTGGGTTCCAGGTTCCACTGGTGAC } \\
\text { TCY TAT GAG CTG ACW CAG CCA C }\end{array}$ \\
\hline $\mathrm{V}_{\lambda}$ 31-Int tag & $\begin{array}{l}\text { СTGGGTTCCAGGTTCCACTGGTGAC } \\
\text { TCT TCT GAG CTG ACT CAG GAC CC }\end{array}$ \\
\hline $\mathrm{V}_{\lambda} 4 \mathrm{ab}$-Int tag & $\begin{array}{l}\text { CTGGGTTCCAGGTTCCACTGGTGAC } \\
\text { CAG CYT GTG CTG ACT CAA TC }\end{array}$ \\
\hline $\mathrm{V}_{\lambda} 4 \mathrm{c}$-Int tag & $\begin{array}{l}\text { СTGGGTTCCAGGTTCCACTGGTGAC } \\
\text { CTG CCT GTG CTG ACT CAG C }\end{array}$ \\
\hline $\mathrm{V}_{\lambda} 5 / 9-$ Int tag & $\begin{array}{l}\text { CTGGGTTCCAGGTTCCACTGGTGAC } \\
\text { CAG SCT GTG CTG ACT CAG CC }\end{array}$ \\
\hline $\mathrm{V}_{\lambda} 6$-Int tag & $\begin{array}{l}\text { СTGGGTTCCAGGTTCCACTGGTGAC } \\
\text { AAT TTT ATG CTG ACT CAG CCC CAC T }\end{array}$ \\
\hline $\mathrm{V}_{\lambda} 7 / 8$-Int tag & $\begin{array}{l}\text { CTGGGTTCCAGGTTCCACTGGTGAC } \\
\text { CAG RCT GTG GTG ACY CAG GAG }\end{array}$ \\
\hline $\mathrm{V}_{\lambda} 10$-Int tag & $\begin{array}{l}\text { СTGGGTTCCAGGTTCCACTGGTGAC } \\
\text { CAG GCA GGG CWG ACT CAG }\end{array}$ \\
\hline Reverse primer & $5^{\prime}-3^{\prime}$ sequence \\
\hline $\mathrm{C}_{\lambda}$-int & GGG YGG GAA CAG AGT GAC C \\
\hline
\end{tabular}

6. XhoI.

7. T4 DNA Ligase.

8. Competent cells.

9. DNA loading buffer.

10. Ampicillin $(100 \mathrm{mg} / \mathrm{mL})$ : dissolve $500 \mathrm{mg}$ of ampicillin in $4 \mathrm{~mL} \mathrm{ddH_{2 }}$ O. Mix until all ampicillin is completely dissolved. Adjust the volume to $5 \mathrm{~mL}$ with $\mathrm{ddH}_{2} \mathrm{O}$. Mix it again. Sterilize the ampicillin stock solution by filtering through a $0.22 \mu \mathrm{m}$ membrane. Store at $-20{ }^{\circ} \mathrm{C}$.

11. LB agar plates containing ampicillin: dissolve $5 \mathrm{~g}$ of tryptone, $10.0 \mathrm{~g}$ of yeast extract, $10.0 \mathrm{~g}$ of $\mathrm{NaCl}$, and $15.0 \mathrm{~g}$ of agar in $1 \mathrm{~L}$ of $\mathrm{ddH}_{2} \mathrm{O}$. The agar will not dissolve until autoclaved. Autoclave for $15 \mathrm{~min}$ and then allow it to cool until the bottle can be held with bare hands. Add $1 \mathrm{~mL}$ of ampicillin (100 mg/ $\mathrm{mL}$ ). Invert to mix thoroughly. Carefully pour out into sterile 


\section{Table 9}

Other primers used in this study

\begin{tabular}{|c|c|}
\hline $\begin{array}{l}\text { Forward } \\
\text { primer }\end{array}$ & $5^{\prime}-3^{\prime}$ \\
\hline SP & CTGGGTTCCAGGTTCC \\
\hline $\mathrm{C}_{\mathrm{H}} \mathrm{F}$ new & ACCGTCTCCTCAGCCAGCACCAAAGGC \\
\hline $\mathrm{C}_{\mathrm{K}} \mathrm{F}$ new & CGAACTGTGGCTGCACCAAGCGTGTTTATC \\
\hline $\mathrm{C}_{\lambda} \mathrm{F}$ new & CCCAAGGCTGCCCCCTCCGTGACACTG \\
\hline $\mathrm{LF}_{\mathrm{h} / 1}$ & CCGGAATTCGCCACCATGGAGACGGATACGCTGCTCCTG \\
\hline $\mathrm{LF}_{\mathrm{h} / 1}$ & CCGGAATTCGCCACCATGGAGACGGATACGCTGCTCCTG \\
\hline $\mathrm{LF}_{\mathrm{K}}$ & CCGGAGCTCGCCACCATGGAGACGGATACGCTGCTCCTG \\
\hline LF2 new & $\begin{array}{l}\text { GAGACGGATACGCTGCTCCTGTGGGTTTTGCTGCTGTGGGTTCCAGGTTCCAC } \\
\text { TGGT }\end{array}$ \\
\hline $\begin{array}{l}\text { Reverse } \\
\text { primer }\end{array}$ & $5^{\prime}-3^{\prime}$ \\
\hline $\mathrm{V}_{\mathrm{H}} \mathrm{R}$ new & GGTGCTGGCTGAGGAGACGGT \\
\hline $\mathrm{C}_{\mathrm{H}} \mathrm{R}$ new & ATAAGAATGCGGCCGCTCATTTACCCGGAGACAG \\
\hline $\mathrm{V}_{\mathrm{K}} \mathrm{R}$ new & TGGTGCAGCCACAGTTCG \\
\hline $\mathrm{C}_{\mathrm{k}} \mathrm{r}$ new & ATAAGAATGCGGCCGCTTAGCTGCATTCGCCCCTG \\
\hline $\mathrm{V}_{\lambda} \mathrm{R}$ new & AGGGGGCAGCCTTGGG \\
\hline $\mathrm{C}_{\lambda} \mathrm{r}$ new & ATAAGAATGCGGCCGCTCAGCTGCACTCGGTTGGG \\
\hline
\end{tabular}

plastic petri dishes. Allow the dishes to set and then store wrapped in plastic in the cold room.

\section{6 mAb Expression}

1. NanoDrop 2000/2000c spectrophotometer.

2. Plasmids purification kit.

3. Dulbecco's Modified Eagle Medium (DMEM).

4. FBS.

5. Penicillin-streptomycin and liquid.

6. Culture medium: DMEM with $10 \%$ FBS, as well as $1 \times$ penicillin-streptomycin.

7. HEPES-buffered saline (HBS) buffer: Weigh $8.766 \mathrm{~g} \mathrm{NaCl}$

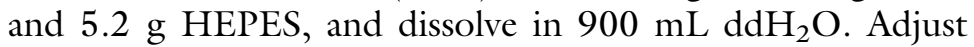
the $\mathrm{pH}$ to 7.4 using $0.5 \mathrm{M} \mathrm{NaOH}$. Sterilize the buffer by autoclaving for $15 \mathrm{~min}$ at $121^{\circ} \mathrm{C}$ or by filter sterilization.

8. Trypsin-EDTA $(0.05 \%)$ and phenol red. 


\subsection{Binding Characterization for the mAbs}

9. $1 \mathrm{mg} / \mathrm{mL}$ polyethylenimine (PEI) in HBS buffer. Sterilize the PEI solution by filtering through a $0.22 \mu \mathrm{m}$ membrane. Store at $4{ }^{\circ} \mathrm{C}$.

10. Goat anti-Human IgG $(\mathrm{H}+\mathrm{L})$ Secondary Antibody, HRP.

11. Nitrocellulose membrane.

12. SDS-PAGE running buffer $(10 \times)$ : Dissolve $30.0 \mathrm{~g}$ of Tris base, $144.0 \mathrm{~g}$ of glycine, and $10.0 \mathrm{~g}$ of SDS in $800 \mathrm{~mL}$ of $\mathrm{H}_{2} \mathrm{O}$. Then add $\mathrm{H}_{2} \mathrm{O}$ to $1 \mathrm{~L}$. Store the running buffer at room temperature and dilute to $1 \times$ before use.

13. SDS-PAGE loading buffer $(5 \times)$.

14. Transfer buffer: Dissolve $6.04 \mathrm{~g}$ of Tris base and $28.8 \mathrm{~g}$ of glycine together in $1.6 \mathrm{~L}$ of $\mathrm{ddH}_{2} \mathrm{O}$. Then add $200 \mathrm{~mL}$ of methanol and mix. At last, add $\mathrm{ddH}_{2} \mathrm{O}$ to a final volume of $2 \mathrm{~L}$.

1. Biacore T100 system.

2. Sensor Chip Protein A.

3. Biacore T100 evaluation software, version 1.0.

4. HBS-EP buffer $(10 \times)$.

\section{Methods}

\subsection{Isolation of PBMCs (0.5 Day)}

1. Collect $10 \mathrm{~mL}$ of whole blood, using a $\mathrm{K}_{2}$ EDTA Tube, from a convalescent Zika patient or a healthy donor with informed consent ( see Note 5).

2. Dilute the anticoagulated blood with $10 \mathrm{~mL}$ PBS (one volume of the original blood).

3. Invert the density gradient medium bottle several times to ensure thorough mixing.

4. Add $13 \mathrm{~mL}$ of density gradient medium to a $50 \mathrm{~mL}$ centrifuge tube with a conical bottom.

5. Carefully layer the diluted blood sample onto the density gradient medium solution ( see Note 6).

6. Centrifuge at $500 \times g$ for $25 \mathrm{~min}$ at room temperature (see Notes 7 and 8 ).

7. Draw off the upper layer containing plasma and platelets using a sterile pipette, leaving the PBMC layer undisturbed at the interface. Aliquot $1 \mathrm{~mL}$ of the upper layer per vial, which contains the plasma, and store them at $-80{ }^{\circ} \mathrm{C}$ (Fig. 1).

8. Transfer the layer of PBMCs to a sterile $50 \mathrm{~mL}$ centrifuge tube using a sterile pipette ( see Note 9). 


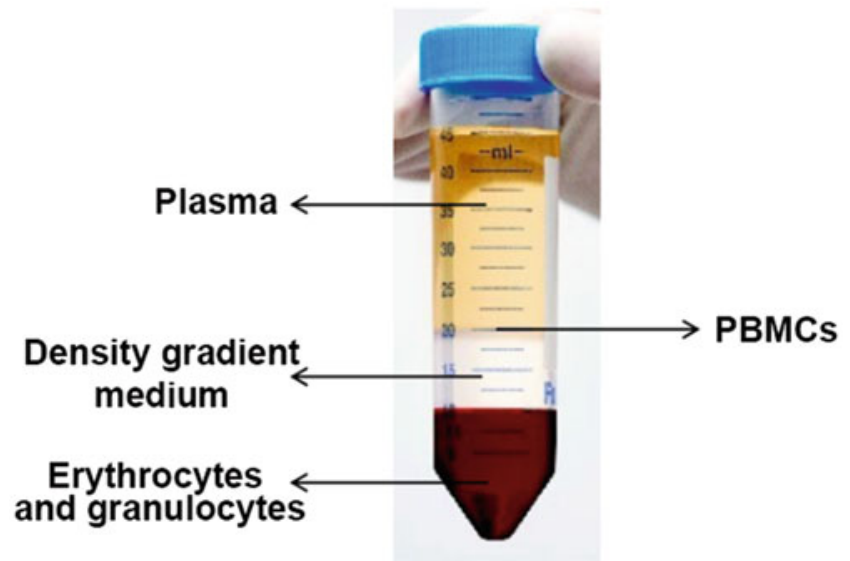

Fig. 1 Layers of density gradient medium solution and whole blood after centrifugation. Layer the diluted blood sample onto the density gradient medium solution. After centrifugation, four layers could be observed. They are, from top to bottom, plasma, PBMCs, density gradient medium solution, and erythrocytes and granulocytes, respectively

9. Add PBS until the total volume reaches $15 \mathrm{~mL}$ ( 1.5 volumes of the original blood). Resuspend the cells by gently drawing them in and out of a pipette.

10. Centrifuge at $500 \times g$ for $15 \mathrm{~min}$ at room temperature, and discard the supernatant.

11. Add $15 \mathrm{~mL}$ PBS to resuspend the cells. Mix thoroughly and transfer $50 \mu \mathrm{L}$ of cell suspension in a $1.5 \mathrm{~mL}$ tube for cell counting.

12. Load $10 \mu \mathrm{L}$ of cell suspension into a cell counting chamber.

13. Insert the chamber into an automated cell counter and run the counting.

14. Repeat step $\mathbf{1 0}$ in this section.

15. Quickly resuspend the cell pellet by adding freezing medium to a cell density of $1 \times 10^{7} / \mathrm{mL}($ see Note 10$)$.

16. Aliquot $1 \mathrm{~mL}$ of the cell-medium mixture per vial, and place in a freezing container.

17. Freeze the cells overnight at $-80{ }^{\circ} \mathrm{C}$.

18. Transfer vials to a liquid $\mathrm{N}_{2}$ tank for storage (see Note 11 ).

3.2 Preparation

of Cells for Flow

Cytometry (0.5 Day)
1. Samples used for staining are designed as follows:

(a) Zika patient PBMCs stained with Zika E protein, as well as a panel of memory B-cell markers (see Note 12). 
(b) Healthy donor PBMCs stained with Zika E protein, as well as a panel of memory B-cell markers (negative control).

(c) Healthy donor PBMCs stained with MERS-RBD protein (positive control for anti-His antibody).

2. Transfer a vial containing the frozen PBMCs of either a convalescent Zika patient or a healthy donor from the liquid $\mathrm{N}_{2}$ tank, and place them into a $37^{\circ} \mathrm{C}$ water bath ( see Note 13 ).

3. Gently swirl the vial in the $37{ }^{\circ} \mathrm{C}$ water bath, and quickly thaw the cells $(<1 \mathrm{~min})$ until there is just a small bit of ice left in the vial.

4. Transfer the vials into a hood. Before opening, wipe the outside of the vials with $70 \%$ ethanol.

5. Transfer the thawing cells into a centrifuge tube $(15 \mathrm{~mL})$ containing $10 \mathrm{~mL}$ of pre-warmed culture medium.

6. Centrifuge the cell suspension at $500 \times g$ for $5 \mathrm{~min}$ at room temperature.

7. Decant the supernatant without disturbing the cell pellet.

8. Gently resuspend the cells in FACS buffer, $400 \mu \mathrm{L}$ per $10^{7}$ cells.

9. Transfer $1 \times 10^{5}$ cells $(4 \mu \mathrm{L})$ into a FACS tube containing $200 \mu \mathrm{L}$ of FACS buffer as control cells without staining.

10. Add purified Zika E protein to the cells to a final concentration of $100 \mathrm{nM}$.

Calculation: Predicted molecular weight of Zika E protein $=45 \mathrm{kDa}$.

Volume $=400 \mu \mathrm{L}$.

Target molar concentration $=100 \mathrm{nM}$.

Concentration of Zika E protein $=1 \mathrm{mg} / \mathrm{mL}$.

Thus, we need to transfer Zika E protein to the cells in a volume of as follows:

$\left(400 \times 10^{-6} \mathrm{~L}\right) \times\left(100 \times 10^{-9} \mathrm{~mol} / \mathrm{L}\right) \times\left(45 \times 10^{3} \mathrm{~g} / \mathrm{mol}\right) /$

$1 \mathrm{~g} / \mathrm{L}=1.8 \times 10^{-6} \mathrm{~L}=1.8 \mu \mathrm{L}$.

11. Keep the mixture on ice for $1 \mathrm{~h}$.

12. Add $10 \mathrm{~mL}$ of FACS buffer to the cells and pellet the cells by centrifuging at $500 \times g$ for $5 \mathrm{~min}$ at $4{ }^{\circ} \mathrm{C}$. Decant the supernatant without disturbing the cell pellet (see Note 14).

13. Resuspend the cells with $100 \mu \mathrm{L}$ of FACS buffer per $10^{7}$ cells (see Note 15).

14. Prepare staining master mix in a $1.5 \mathrm{~mL}$ microcentrifuge tube (see Table 1) and store them at $4{ }^{\circ} \mathrm{C}$ in the dark before use.

15. Add $100 \mu \mathrm{L}$ of the staining master mix to cells that prepared in step 13 in this section. Incubate them on ice for $30 \mathrm{~min}$. 


\subsection{Preparation of Single-Color Compensation Controls (1 h)}

16. Add $10 \mathrm{~mL}$ of FACS buffer to the mixture of cells and antibodies in the last step and pellet the cells by centrifugation at $500 \times g$ for $5 \mathrm{~min}$ at $4{ }^{\circ} \mathrm{C}$. Decant the supernatant without disturbing the pellet.

17. Resuspend the cells with $0.5 \mathrm{~mL}$ FACS buffer. Place the tube on ice and avoid light before cell sorting.

1. Label a FACS tube for each of the six fluorochromes that will be used in the cell sorting. Add $0.5 \mathrm{~mL}$ of FACS buffer into each tube.

2. Mix compensation beads by vigorously inverting at least ten times.

3. Add $50 \mu \mathrm{L}$ of compensation beads into each tube.

4. Add $1 \mu \mathrm{L}$ of fluorochrome-conjugated antibody to the appropriately labelled tube. Mix well by flicking, inverting vigorously, or pulse vortexing ( see Note 16).

5. Incubate at room temperature for $15 \mathrm{~min}$ in the dark.

6. Add $4 \mathrm{~mL}$ of FACS buffer to each tube and centrifuge at $500 \times g$ for $5 \mathrm{~min}$ at $4{ }^{\circ} \mathrm{C}$.

7. Decant the supernatant and add $0.5 \mathrm{~mL}$ of FACS buffer to each tube.

8. Mix briefly by flicking or pulse vortexing before analysis.

1. Use the Instrument Setup feature to automatically calculate compensation settings. Load the samples as indicated by the instructions of the instrument.

2. After calculation of the compensation values, save and link them.

3. Load the negative control sample (healthy donor stained with Zika E protein, as well as a panel of memory B-cell markers) onto the cytometer and gate on the $\mathrm{CD}^{-} \mathrm{CD}^{-} 6^{-} \mathrm{CD} 235 \mathrm{a}^{-} \mathrm{CD} 19^{+} \mathrm{CD} 27^{+} \mathrm{CD} 38^{-} \mathrm{IgG}^{+}$memory $\mathrm{B}$ cells as shown in Fig. 2A (see Notes 18 and 19).

4. For the negative control, analyze the PE shift of the lymphocyte subpopulation as displayed in Fig. 2B.

5. Load the healthy PBMCs sample stained with MERS-RBD (Fig. 2C). Analyze the PE shift of the lymphocyte subpopulation ( see Note 20).

6. Load the Zika PBMCs sample stained with Zika E protein and memory B-cell markers. Gate the target cells as in Fig. 2D.

7. Adjust the flow rate so that the event rate is approximately 8000 events/s. 

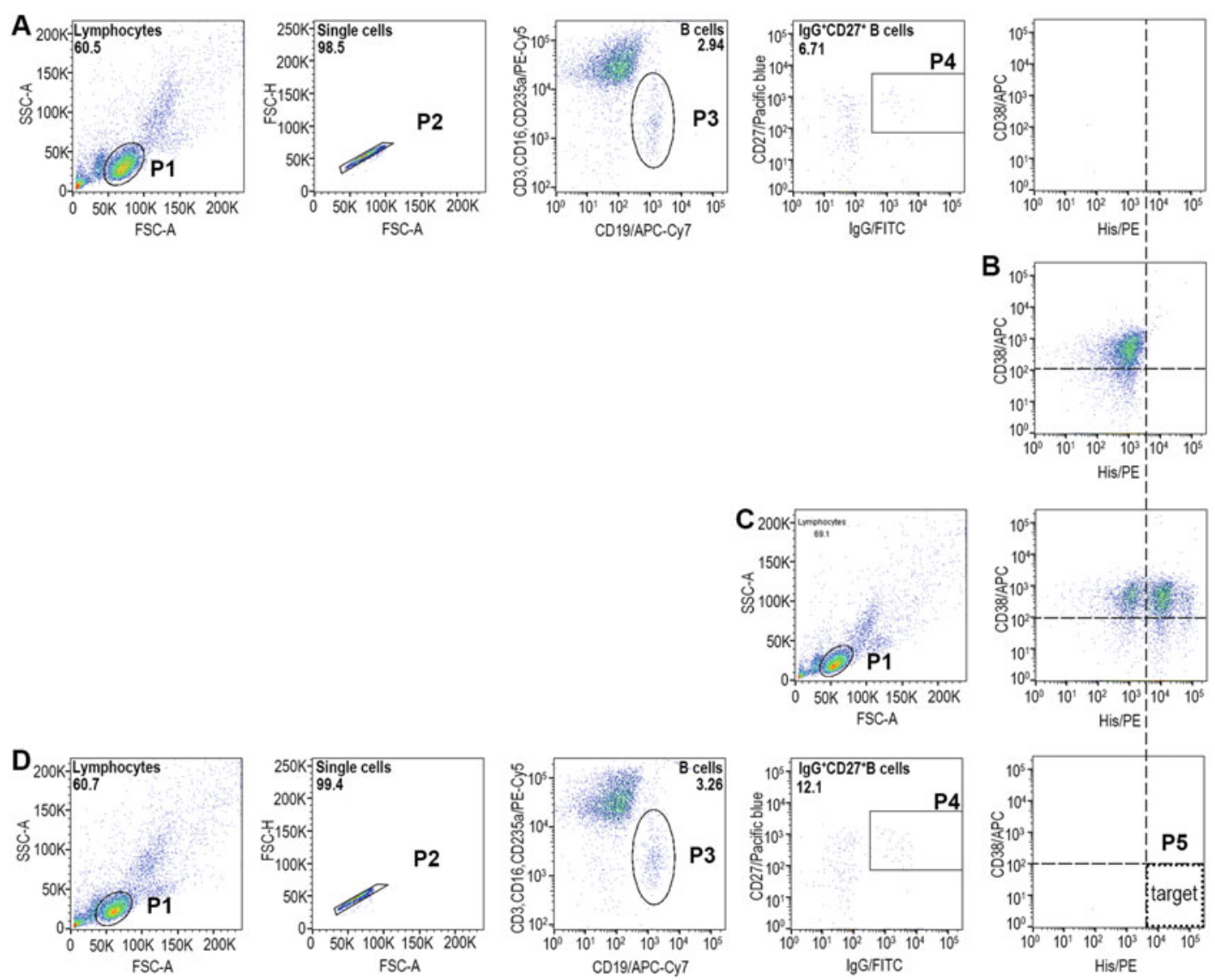

Fig. 2 Gating strategy for Zika E-specific memory B-cell population. (A) Healthy donor PBMCs stained with Zika $E$ protein, as well as a panel of memory B-cell markers. Cells were first gated based on the FSC-A and SSC-A (P1). Single cells in P1 (P2) were further analyzed for marker expression. In particular, cells showing expression of CD19, but not CD3, CD16, or CD235a, were gated out (P3). B cells, represented by P3, were further analyzed for expression of CD27 and hlgG (P4). At last, cells in P4 were analyzed for the expression of CD38 and the PE shift. (B) P1 cells in panel (A) were analyzed for the expression of CD38 and the PE shift. (C) Healthy donor PBMCs stained with MERS-RBD, which contains a $6 \times$ His tag at its C-terminus. The lymphocyte subpopulation (P1) was analyzed for the expression of CD38 and the PE shift. (D) Zika patient PBMCs stained with Zika E protein and memory B-cell markers. The cells gated as those in panel (A). The target cells (P5) were sorted in the 96-well plate (one per well) for further analysis

8. Collect the cells (one per well) into a 96-well PCR plate that is preloaded with $8 \mu \mathrm{L}$ DEPC-treated $\mathrm{ddH}_{2} \mathrm{O}$.

9. Plates are then sealed with an adhesive film and immediately frozen on dry ice before storage at $-80^{\circ} \mathrm{C}$.

\subsection{Determination of the Ig Genes in the Isolated Single Cells (2 Days)}

1. Mix and briefly centrifuge each component in the RT-PCR synthesis system for the first-strand cDNA before use.

2. Combine the components in Table 10 in a $0.5 \mathrm{~mL}$ tube. 
Table 10

Primers and dNTP for the first-strand cDNA synthesis

\begin{tabular}{|c|c|c|}
\hline Component & For 1 cell $(\mu \mathrm{L})$ & For 100 cells $(\mu L)$ \\
\hline \multicolumn{3}{|l|}{ Primers $(1.5 \mu g / \mu L)$} \\
\hline IgM-RT & 0.1 & 10 \\
\hline Igd-RT & 0.1 & 10 \\
\hline Ige-RT & 0.1 & 10 \\
\hline Igal-RT & 0.1 & 10 \\
\hline Iga2-RT & 0.1 & 10 \\
\hline Igg-RT & 0.1 & 10 \\
\hline Cк-new RT & 0.1 & 10 \\
\hline $\mathrm{C} \lambda$-new-ext & 0.1 & 10 \\
\hline $10 \mathrm{mM}$ dNTP mix & 1 & 100 \\
\hline DEPC-treated water & 0.95 & 20 \\
\hline Total & 2.75 & 275 \\
\hline
\end{tabular}

Table 11

cDNA Synthesis Mix for the first-strand cDNA synthesis

\begin{tabular}{llll}
\hline Component & For 1 cell $(\mu \mathrm{L})$ & For 100 cells $(\mu \mathrm{L})$ \\
\hline $10 \times$ RT buffer & 2 & 200 & \\
$25 \mathrm{mM} \mathrm{MgCl} 2$ & 4 & 400 & \\
$0.1 \mathrm{M} \mathrm{DTT}$ & 2 & 200 & \\
\hline & & & 100 \\
\hline RNase inhibitor $(40 \mathrm{U} / \mu \mathrm{L})$ & 1 & 25 \\
Reverse transcriptase $(200 \mathrm{U} / \mu \mathrm{L})$ & 0.25 & 925 \\
\hline Total & 9.25 & \\
\hline
\end{tabular}

3. Add $2.75 \mu \mathrm{L}$ of mixed primers and dNTP (see Table 10) into each well containing the collected single cells prepared in step 9 in Subheading 3.4.

4. Incubate the plate at $65^{\circ} \mathrm{C}$ for $5 \mathrm{~min}$ and then place it on ice for at least $1 \mathrm{~min}$.

5. Prepare the following cDNA Synthesis Mix in a $1.5 \mathrm{~mL}$ tube, adding each component in Table 11 in the indicated order. 
Table 12

Primer mix for the PCRa

\begin{tabular}{|c|c|c|c|c|c|}
\hline$V_{H}(100 \mathrm{nM})$ & Amount $(\mu \mathrm{L})$ & $V_{\mathrm{K}}(100 \mathrm{nM})$ & Amount $(\mu \mathrm{L})$ & $\mathbf{V}_{\lambda}(100 \mathrm{nM})$ & Amount ( $\mu \mathrm{L})$ \\
\hline $\mathrm{V}_{\mathrm{H}} \mathrm{l}-\mathrm{Ext}$ & 10 & $\mathrm{~V}_{\mathrm{\kappa}} \mathrm{l} / 2$-Ext & 10 & $\mathrm{~V}_{\lambda} \mathrm{l}$-Ext & 10 \\
\hline $\mathrm{V}_{\mathrm{H}} 2$-Ext & 10 & $\mathrm{~V}_{\kappa} 3$-Ext & 10 & $\mathrm{~V}_{\lambda} 2$-Ext & 10 \\
\hline $\mathrm{V}_{\mathrm{H}} 3$-Ext & 10 & $\mathrm{~V}_{\mathrm{K}} 4 / 5$-Ext & 10 & $\mathrm{~V}_{\lambda} 3$-Ext & 10 \\
\hline $\mathrm{V}_{\mathrm{H}} 4$-Ext & 10 & $\mathrm{~V}_{\kappa} 6 / 7-\mathrm{Ext}$ & 10 & $\mathrm{~V}_{\lambda} 31$-Ext & 10 \\
\hline $\mathrm{V}_{\mathrm{H}} 5$-Ext & 10 & $\mathrm{C}_{\mathrm{K}}$-ext & 10 & $\mathrm{~V}_{\lambda} 4 \mathrm{ab}-\mathrm{Ext}$ & 10 \\
\hline $\mathrm{V}_{\mathrm{H}} 6$-Ext & 10 & & & $\mathrm{~V}_{\lambda} 4 \mathrm{c}-\mathrm{Ext}$ & 10 \\
\hline IgG-exta & 10 & & & $\begin{array}{l}\mathrm{V}_{\lambda} 5 / 9-\mathrm{Ext} \\
\mathrm{V}_{\lambda} 6 \text {-Ext } \\
\mathrm{V}_{\lambda} 7 / 8 \text {-Ext } \\
\mathrm{V}_{\lambda} 10 \text {-Ext } \\
\mathrm{C}_{\lambda} \text {-new-ext }\end{array}$ & $\begin{array}{l}10 \\
10 \\
10 \\
10 \\
10\end{array}$ \\
\hline DEPC-treated water & 130 & & 150 & & 90 \\
\hline Total amount & 200 & & 200 & & 200 \\
\hline
\end{tabular}

6. Add 9.25 $\mu \mathrm{L}$ of cDNA Synthesis Mix (see Table 11) to each well, mix gently, and collect by centrifugation at $15,000 \times g$ at $4{ }^{\circ} \mathrm{C}$ for $15 \mathrm{~s}$.

7. The RT reaction is performed at $55^{\circ} \mathrm{C}$ for $60 \mathrm{~min}$ and terminated at $85{ }^{\circ} \mathrm{C}$ for $5 \mathrm{~min}$. Chill on ice and then store at $-20^{\circ} \mathrm{C}$ until use.

8. Prepare primers for the PCRa (see Tables 3-5). The amount for 100 reactions is listed in Table 12.

9. Perform the PCRa to amplify the Ig genes. Prepare the reaction system as indicated in Table 13 (see Note 21 ).

The cycling conditions for the PCRa are shown in Table 14.

Store the PCRa products at $-20{ }^{\circ} \mathrm{C}$ until further use.

10. Prepare primers for the PCRb (see Tables 6-8). The amount listed in Table 15 is for 100 reactions.

11. Perform the PCRb to amplify the Ig genes. Prepare reaction system as indicated in Table 16 (see Notes 21 and 22).

The cycling conditions for the PCRb are indicated in Table 17.

12. Load the samples onto an agarose gel (1.2\%), and separate the DNAs by electrophoresis.

13. A typical band size for $\mathrm{V}_{\mathrm{H}}, \mathrm{V}_{\mathrm{\kappa}}$ and $\mathrm{V}_{\lambda}$ is approximately $400 \mathrm{bp}$, as displayed in Fig. 3. 


\section{Table 13}

\section{Reaction system for the PCRa}

\begin{tabular}{llll}
\hline Component & For $\mathbf{V}_{\mathbf{H}}(\mu \mathrm{L})$ & For $\mathbf{V}_{\boldsymbol{\kappa}}(\mu \mathrm{L})$ & For $\mathbf{V}_{\lambda}(\mu \mathrm{L})$ \\
\hline RT product & 2 & 2 & 2 \\
\hline DNA polymerase (for single-cell PCR) & 0.4 & 0.4 & 0.4 \\
\hline $10 \mathrm{mM} \mathrm{dNTP} \mathrm{mix}$ & 0.4 & 0.4 & 0.4 \\
\hline Primers for $\mathrm{V}_{\mathrm{H}}$ & 2 & -- & -- \\
\hline Primers for $\mathrm{V}_{\boldsymbol{\kappa}}$ & -- & 2 & -- \\
\hline Primers for $\mathrm{V}_{\boldsymbol{\lambda}}$ & -- & -- & 2 \\
\hline $10 \times$ PCR buffer & 2 & 2 & 2 \\
\hline $5 \times$ Q solution & 4 & 4 & 4 \\
\hline ddH $\mathrm{H}_{2} \mathrm{O}$ & 9.2 & 9.2 & 9.2 \\
\hline Total & 20 & 20 & 20 \\
\hline
\end{tabular}

Table 14

The cycling conditions for the PCRa

\begin{tabular}{lllll}
\hline & Temperature & For $\mathbf{V}_{\mathbf{H}}$ & For $\mathbf{V}_{\boldsymbol{\kappa}}$ & For $\mathbf{V}_{\boldsymbol{\lambda}}$ \\
\hline \multirow{3}{*}{35 cycles } & $95{ }^{\circ} \mathrm{C}$ & $5 \mathrm{~min}$ & $5 \mathrm{~min}$ & $5 \mathrm{~min}$ \\
& $95{ }^{\circ} \mathrm{C}$ & $30 \mathrm{~s}$ & $30 \mathrm{~s}$ & $30 \mathrm{~s}$ \\
& $55^{\circ} \mathrm{C}$ & $30 \mathrm{~s}$ & $30 \mathrm{~s}$ & - \\
& $50^{\circ} \mathrm{C}$ & - & - & $30 \mathrm{~s}$ \\
& $72{ }^{\circ} \mathrm{C}$ & $30 \mathrm{~s}$ & $30 \mathrm{~s}$ & $30 \mathrm{~s}$ \\
& $72{ }^{\circ} \mathrm{C}$ & $7 \mathrm{~min}$ & $7 \mathrm{~min}$ & $7 \mathrm{~min}$ \\
\hline
\end{tabular}

3.6 Construction of the Expression Vectors (See Note 24) (4 Days)
14. Cut out the $\sim 400$ bp bands and extract the DNA segments using a Gel Extraction Micro Kit according to the manufacturer's instructions.

15. Sequence the bands using primer SP.

16. Analyze the sequences by using the IgBlast tool (https://www. ncbi.nlm.nih.gov/igblast/index.cgi) or IMGT (http://www. imgt.org/) to identify germline $\mathrm{V}(\mathrm{D}) \mathrm{J}$ gene segments with the highest identity ( see Note 23).

1. Perform the PCRc. Prepare reaction system as indicated in Table 18. 
Table 15

Primer mix for the PCRb

\begin{tabular}{|c|c|c|c|c|c|}
\hline$V_{H}(100 \mathrm{nM})$ & Amount $(\mu \mathrm{L})$ & $V_{\kappa}(100 n M)$ & Amount ( $\mu \mathrm{L})$ & $\mathbf{V}_{\lambda}(100 \mathrm{nM})$ & Amount ( $\mu \mathrm{L})$ \\
\hline $\mathrm{V}_{\mathrm{H}} \mathrm{l}$-Int tag & 10 & Vкl-Int tag & 10 & $\mathrm{~V}_{\lambda} \mathrm{l}$-Int tag & 10 \\
\hline $\mathrm{V}_{\mathrm{H}} 2$-Int tag & 10 & Vк2-Int tag & 10 & $\mathrm{~V}_{\lambda} 2$-Int tag & 10 \\
\hline $\mathrm{V}_{\mathrm{H}} 3$-Int tag & 10 & Vк3-Int tag & 10 & $\mathrm{~V}_{\lambda} 3$-Int tag & 10 \\
\hline $\mathrm{V}_{\mathrm{H}} 4$-Int tag & 10 & Vк4-Int tag & 10 & $\mathrm{~V}_{\lambda}$ 31-Int tag & 10 \\
\hline $\mathrm{V}_{\mathrm{H}} 5$-Int tag & 10 & Vк5-Int tag & 10 & $\mathrm{~V}_{\lambda} 4 \mathrm{ab}$-Int tag & 10 \\
\hline $\mathrm{V}_{\mathrm{H}} 6$-Int tag & 10 & Vк6-Int tag & 10 & $\mathrm{~V}_{\lambda} 4 \mathrm{c}$-Int tag & 10 \\
\hline IgG-extb & 10 & $\begin{array}{l}\text { Vк7-Int tag } \\
\text { Ск-int }\end{array}$ & $\begin{array}{l}10 \\
10\end{array}$ & $\begin{array}{l}\mathrm{V}_{\lambda} 5 / 9 \text {-Int tag } \\
\mathrm{V}_{\lambda} 6 \text {-Int tag } \\
\mathrm{V}_{\lambda} 7 / 8 \text {-Int tag } \\
\mathrm{V}_{\lambda} 10 \text {-Int tag } \\
\mathrm{C}_{\lambda} \text {-int }\end{array}$ & $\begin{array}{l}10 \\
10 \\
10 \\
10 \\
10\end{array}$ \\
\hline DEPC-treated water & 130 & & 120 & & 90 \\
\hline Total amount & 200 & & 200 & & 200 \\
\hline
\end{tabular}

\section{Table 16}

\section{Reaction system for the PCRb}

\begin{tabular}{llll}
\hline Component & For $\mathbf{V}_{\mathbf{H}}(\mu \mathrm{L})$ & For $\mathbf{V}_{\kappa}(\mu \mathrm{L})$ & For $\mathbf{V}_{\lambda}(\mu \mathrm{L})$ \\
\hline PCRa product & 1 & 1 & 1 \\
\hline DNA polymerase (for single-cell PCR) & 0.4 & 0.4 & 0.4 \\
\hline $10 \mathrm{mM} \mathrm{dNTP} \mathrm{mix}$ & 0.4 & 0.4 & 0.4 \\
\hline Primers for $\mathrm{V}_{\mathrm{H}}$ & 2 & -- & -- \\
\hline Primers for $\mathrm{V}_{\kappa}$ & -- & 2 & -- \\
\hline Primers for $\mathrm{V}_{\boldsymbol{\lambda}}$ & -- & -- & 2 \\
\hline $10 \times$ PCR buffer & 2 & 2 & 2 \\
\hline $5 \times \mathrm{Q}$ solution & 4 & 4 & 4 \\
\hline ddH $\mathrm{H}_{2} \mathrm{O}$ & 10.2 & 10.2 & 10.2 \\
\hline Total & 20 & 20 & 20 \\
\hline
\end{tabular}

2. The PCR reaction is incubated at $98^{\circ} \mathrm{C}$ for $2 \mathrm{~min}$, followed by 30 cycles of $98^{\circ} \mathrm{C}$ for $10 \mathrm{~s}, 55^{\circ} \mathrm{C}$ for $30 \mathrm{~s}$, and $72{ }^{\circ} \mathrm{C}$ for $60 \mathrm{~s}$, with a final incubation at $72{ }^{\circ} \mathrm{C}$ for $5 \mathrm{~min}$.

3 . Load the samples onto an agarose gel (1.2\%), and separate them by electrophoresis. 
Table 17

The cycling conditions for PCRb

\begin{tabular}{lllll}
\hline & Temperature & For $\mathbf{V}_{\mathbf{H}}$ & For $\mathbf{V}_{\boldsymbol{\kappa}}$ & For $\mathbf{V}_{\boldsymbol{\lambda}}$ \\
\hline \multirow{3}{*}{35 cycles } & $95^{\circ} \mathrm{C}$ & $5 \mathrm{~min}$ & $5 \mathrm{~min}$ & $5 \mathrm{~min}$ \\
& $95^{\circ} \mathrm{C}$ & $30 \mathrm{~s}$ & $30 \mathrm{~s}$ & $30 \mathrm{~s}$ \\
& $58^{\circ} \mathrm{C}$ & $30 \mathrm{~s}$ & $30 \mathrm{~s}$ & -- \\
& $60^{\circ} \mathrm{C}$ & -- & $30 \mathrm{~s}$ & -- \\
& $64{ }^{\circ} \mathrm{C}$ & -- & -- & $30 \mathrm{~s}$ \\
& $72{ }^{\circ} \mathrm{C}$ & $30 \mathrm{~s}$ & $30 \mathrm{~s}$ & $30 \mathrm{~s}$ \\
& $72^{\circ} \mathrm{C}$ & $7 \mathrm{~min}$ & $7 \mathrm{~min}$ & $7 \mathrm{~min}$ \\
\hline
\end{tabular}
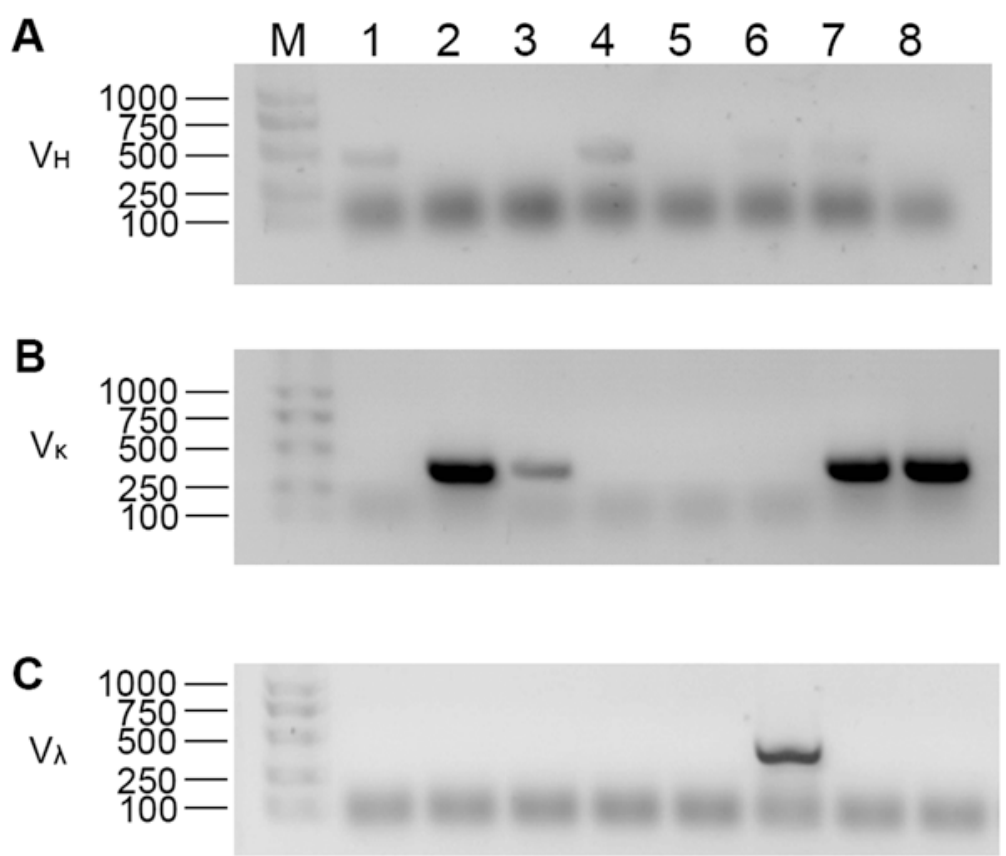

Fig. 3 Typical bands for $V_{H}, V_{\kappa}$, and $V_{\lambda}$ after the second round PCR. After the second round PCR, the DNAs were separated by electrophoresis. The results for $V_{H}, V_{\kappa}$, and $V_{\lambda}$ were displayed in $A, B$, and $C$, respectively

4. Cut out the $\sim 400$ bp bands and extract the DNA segments using a Gel Extraction Kit according to the manufacturer's instructions.

5. The PCR for amplification of the constant regions (see Table 19) is incubated at $98^{\circ} \mathrm{C}$ for $2 \mathrm{~min}$, followed by 30 cycles of $98^{\circ} \mathrm{C}$ for $10 \mathrm{~s}, 55^{\circ} \mathrm{C}$ for $30 \mathrm{~s}$, and $72{ }^{\circ} \mathrm{C}$ for $60 \mathrm{~s}$, with a final incubation at $72{ }^{\circ} \mathrm{C}$ for $5 \mathrm{~min}$. 


\section{Table 18}

Reaction system for the PCRc

\begin{tabular}{llll}
\hline Component & For $\mathbf{V}_{\mathbf{H}}(\mu \mathrm{L})$ & For $\mathbf{V}_{\boldsymbol{\kappa}}(\mu \mathrm{L})$ & For $\mathbf{V}_{\lambda}(\mu \mathrm{L})$ \\
\hline PCRb product & 2 & 2 & 2 \\
\hline $\mathrm{LF} 2$ new $(10 \mu \mathrm{M})$ & 1 & 1 & 1 \\
\hline $\mathrm{V}_{\mathrm{H}} \mathrm{R}$ new $(10 \mu \mathrm{M})$ & 1 & -- & -- \\
\hline $\mathrm{V}_{\mathrm{K}}$ R new $(10 \mu \mathrm{M})$ & -- & 1 & -- \\
\hline $\mathrm{V}_{\lambda}$ R new $(10 \mu \mathrm{M})$ & -- & -- & 1 \\
\hline $10 \times$ PCR buffer & 2 & 2 & 2 \\
\hline High-Fidelity DNA Polymerase & 0.4 & 0.4 & 0.4 \\
\hline 2.5 mM dNTP mix & 1 & 1 & 1 \\
\hline ddH ${ }_{2} \mathrm{O}$ & 12.6 & 12.6 & 12.6 \\
\hline Total & 20 & 20 & 20 \\
\hline
\end{tabular}

Table 19

Reaction system for amplification of the constant regions

\begin{tabular}{llll}
\hline Component & For $\mathbf{C}_{\mathbf{H}}(\mu \mathrm{L})$ & For $\mathbf{C}_{\kappa}(\mu \mathrm{L})$ & For $\mathbf{C}_{\lambda}(\mu \mathrm{L})$ \\
\hline pCAGGS-H $(100 \mathrm{ng} / \mu \mathrm{L})$ & 0.5 & -- & -- \\
\hline pCAGGS-K $(100 \mathrm{ng} / \mu \mathrm{L})$ & -- & 0.5 & -- \\
\hline pCAGGS-L $(100 \mathrm{ng} / \mu \mathrm{L})$ & -- & -- & 0.5 \\
\hline $\mathrm{C}_{\mathrm{H}}$ F new & 1 & -- & -- \\
\hline $\mathrm{C}_{\mathrm{H}}$ R new & 1 & -- & -- \\
\hline $\mathrm{C}_{\mathrm{\kappa}}$ F new & -- & 1 & -- \\
\hline $\mathrm{C}_{\mathrm{\kappa}}$ R new & -- & 1 & -- \\
\hline $\mathrm{C}_{\lambda}$ F new & -- & -- & 1 \\
\hline $\mathrm{C}_{\lambda}$ R new & -- & -- & 1 \\
\hline $10 \times$ PCR buffer & 5 & 5 & 5 \\
\hline High-Fidelity DNA Polymerase & 1 & 1 & 1 \\
\hline 2.5 mM dNTP mix & 4 & 4 & 4 \\
\hline ddH ${ }_{2} \mathrm{O}$ & 37.5 & 37.5 & 37.5 \\
\hline Total & 50 & 50 & 50 \\
\hline
\end{tabular}


Table 20

Reaction system for overlapping PCR to generate the expression cassette

\begin{tabular}{llll}
\hline Component & For $\mathbf{C}_{\mathbf{H}}(\mu \mathrm{L})$ & For $\mathbf{C}_{\mathbf{K}}(\mu \mathrm{L})$ & For $\mathbf{C}_{\lambda}(\mu \mathrm{L})$ \\
\hline $\mathrm{V}_{\mathrm{H}}$ of PCRc & To $0.25 \mu \mathrm{g}$ & -- & -- \\
\hline $\mathrm{C}_{\mathrm{H}}$ & To $0.75 \mu \mathrm{g}$ & -- & -- \\
\hline $\mathrm{V}_{\mathrm{K}}$ of PCRc & -- & To $0.5 \mu \mathrm{g}$ & -- \\
\hline $\mathrm{C}_{\mathrm{K}}$ & -- & To $0.5 \mu \mathrm{g}$ & -- \\
\hline $\mathrm{V}_{\lambda}$ of PCRc & -- & -- & To $0.5 \mu \mathrm{g}$ \\
\hline $\mathrm{C}_{\lambda}$ & -- & -- & To $0.5 \mu \mathrm{g}$ \\
\hline $\mathrm{LF}_{\mathrm{H} / 1}$ & 1 & -- & 1 \\
\hline $\mathrm{LF}_{\mathrm{K}}$ & -- & 1 & -- \\
\hline $\mathrm{C}_{\mathrm{H}} \mathrm{R}$ new & 1 & -- & -- \\
\hline $\mathrm{C}_{\mathrm{K}} \mathrm{R}$ new & -- & 1 & -- \\
\hline $\mathrm{C}_{\lambda} \mathrm{R}$ new & -- & -- & 1 \\
\hline $10 \times$ PCR buffer & 5 & 5 & 5 \\
\hline High-Fidelity DNA Polymerase & 1 & 1 & 1 \\
\hline 2.5 mM dNTP mix & 4 & 4 & 4 \\
\hline ddH ${ }_{2} \mathrm{O}$ & To 50 & To 50 & To 50 \\
\hline Total & 50 & 50 & 50 \\
\hline
\end{tabular}

6. Load the samples onto an agarose gel (1.2\%), and separate them by electrophoresis.

7. Cut out the $\sim 1000 \mathrm{bp}$ bands for $\mathrm{C}_{\mathrm{H}}$ and $\sim 400 \mathrm{bp}$ for $\mathrm{C}_{\mathrm{K}}$ and $\mathrm{C}_{\lambda}$. Extract the DNA segments using a Gel Extraction Kit according to the manufacturer's instructions.

8. Perform overlapping PCR to generate the expression cassette (see Table 20). The PCR reaction is incubated at $98{ }^{\circ} \mathrm{C}$ for $2 \mathrm{~min}$, followed by 30 cycles of $98^{\circ} \mathrm{C}$ for $10 \mathrm{~s}, 55^{\circ} \mathrm{C}$ for $30 \mathrm{~s}$, and $72{ }^{\circ} \mathrm{C}$ for $2 \mathrm{~min}$, with a final incubation at $72{ }^{\circ} \mathrm{C}$ for $5 \mathrm{~min}$.

9. Digest the PCR products from the last step with EcoRI and $X h o I$ for both the heavy and lambda chains. Digest the kappa chain with KpnI and XhoI (see Table 21).

Mix gently and spin down for a few seconds. Incubate at $37^{\circ} \mathrm{C}$ overnight.

10. Purify the digested PCR segment using a Universal DNA Purification Kit according to the manufacturer's instruction.

11. Ligate the expression cassette to the pCAGGS vector (see Table 22). For both heavy and lambda chains, the vector was 


\section{Table 21}

Reaction system to digest the PCR products

\begin{tabular}{llll}
\hline Component & For heavy chain $(\mu \mathrm{L})$ & For kappa chain $(\mu \mathrm{L})$ & For lambda chain $(\mu \mathrm{L})$ \\
\hline Overlapping product & 50 & 50 & 50 \\
\hline $10 \times$ Tango buffer & 20 & 10 & 20 \\
\hline EcoRI & 2 & -- & 2 \\
$X$ Xoi & 2 & 5 & 2 \\
$K p h \mathrm{I}$ & -- & 5 & -- \\
\hline & & & \\
\hline dd ${ }_{2} \mathrm{O}$ & 26 & 30 & 26 \\
\hline Total & 100 & 100 & 100 \\
\hline
\end{tabular}

Table 22

Reaction system to ligate the expression cassette to the pCAGGS vector

\begin{tabular}{llll}
\hline Component & For heavy $(\mu \mathrm{L})$ & For kappa $(\mu \mathrm{L})$ & For lambda $(\mu \mathrm{L})$ \\
\hline Linear vector DNA & To $50 \mathrm{ng}$ & To $50 \mathrm{ng}$ & To $50 \mathrm{ng}$ \\
\hline Insert DNA & To $50 \mathrm{ng}$ & To $25 \mathrm{ng}$ & To $25 \mathrm{ng}$ \\
\hline 10× T4 DNA ligase buffer & 2 & 2 & 2 \\
\hline T4 DNA ligase & 0.4 & 0.4 & 0.4 \\
\hline ddH $_{2} \mathrm{O}$ & To 20 & To 20 & To 20 \\
\hline Total & 20 & 20 & 20 \\
\hline
\end{tabular}

linearized with EcoRI and XhoI. While for kappa chain, the vector was digested by $K p n \mathrm{I}$ and $\mathrm{XhoI}$.

12. Incubate for $1 \mathrm{~h}$ at $22{ }^{\circ} \mathrm{C}$.

13. Use $5 \mu \mathrm{L}$ of the ligation mixture for transformation of $50 \mu \mathrm{L}$ of competent cells according to the manufacturer's instruction.

14. Streak the transformed cells onto LB agar plates containing ampicillin. Incubate at $37^{\circ} \mathrm{C}$ overnight.

15. Pick three single colonies for each construct for sequencing.

16. Align the sequences with the results in step $\mathbf{1 6}$ in Subheading 3.5 .

17. Extract the plasmids with the correct sequences. Mark the plasmid with $\mathrm{Z}$, number, and $\mathrm{H} / \mathrm{K} / \mathrm{L}$. $\mathrm{Z}$ represents Zika virus. The number indicates the sorted single cell. $\mathrm{H} / \mathrm{K} / \mathrm{L}$ stands for the chain encoded by the plasmid (e.g., the plasmid 


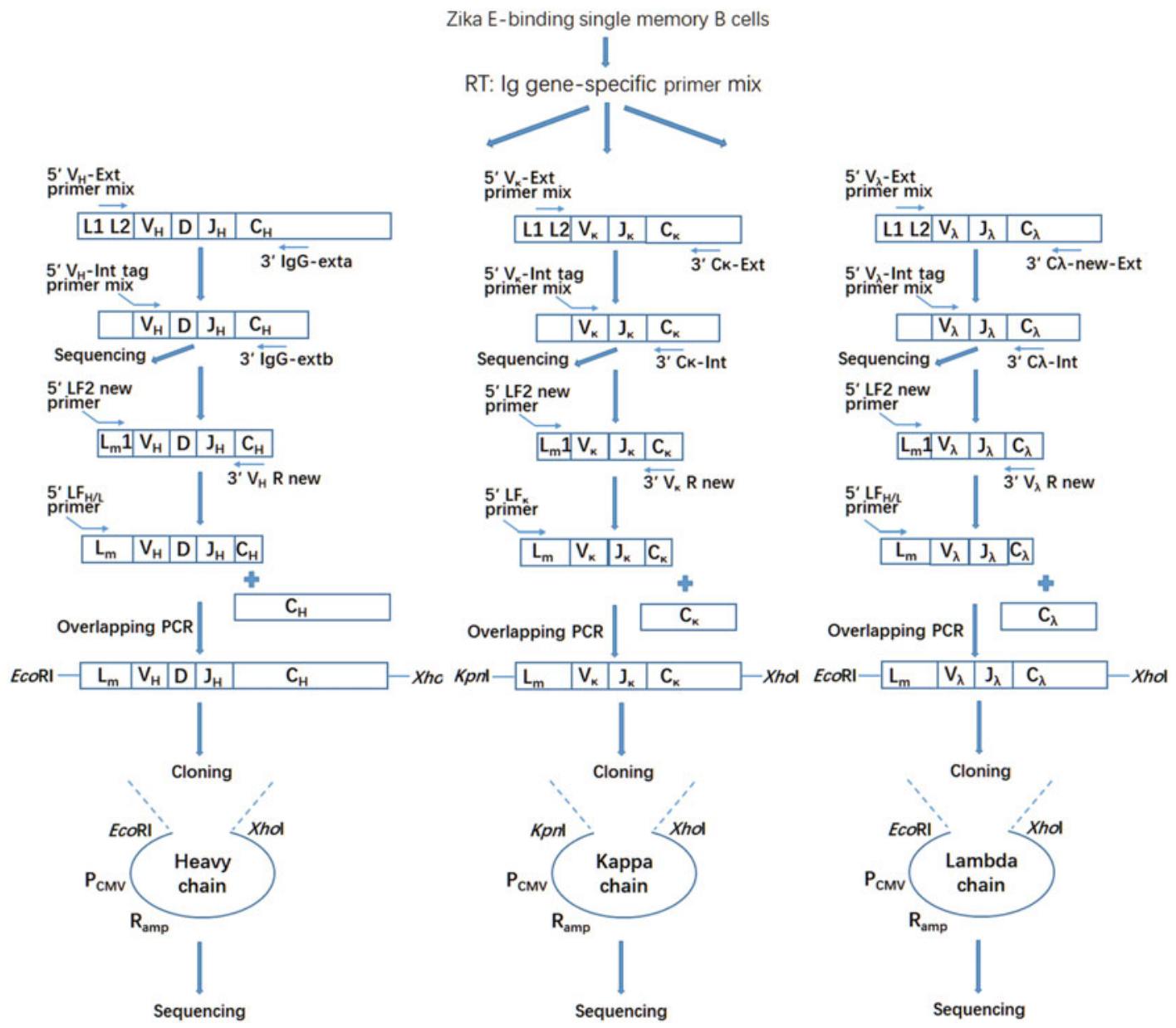

Fig. 4 Strategy to clone and express Zika E-specific human mAbs. The Ig genes from the sorted cells were determined and cloned into the expression vectors by a reported approach with some modifications $[13,18]$. The Ig transcripts in the collected Zika E-interacting memory B cells were first reverse-transcribed into cDNA using the Ig gene-specific primer mix at the single-cell level. Then the variable regions for heavy, kappa, and lambda chains were amplified by nested RT-PCR. The first round PCRs were performed with the forward primer mix specific for the leader region and reverse primers specific for the constant regions of heavy, kappa, and lambda chain, respectively. The second round PCRs were performed with the forward primer mix specific for framework segment FR1 and respective nested reverse primers specific for the heavy, kappa, and lambda constant regions. Then the PCR products were separated by electrophoresis and sent for sequencing. In terms of the correct segments, another round of PCR (PCRc) was performed with the forward primer containing the signal peptide of mouse $\lg _{\mathrm{K}}$ and reverse primer paired with the framework segment FR4. Then the resultant PCR segments were overlapped with the respective constant region to get the full expression cassettes for each chain, which were then ligated to the linearized pCAGGS vector. All expression plasmids were sequenced and aligned with those in PCRb

pCAGGS-Z23H encodes the heavy chain of the 23rd sorted cell).

18. The generation of vectors for $\mathrm{mAb}$ expression is displayed in schematic diagram in Fig. 4. 


\subsection{Expression of the Recombinant mAbs (4 Days)}

3.8 SPR Analysis to Determine the Specificity and Binding Affinity of mAbs to Zika $E$ Protein (See Notes 26 and 27) (1 Day)
1. Prepare the plasmids containing paired mAbs using a Plasmid Purification Kit according to the manufacturer's instruction.

2. Determine the concentration of each purified plasmid with a NanoDrop.

3. The day before transfection, plate $1 \times 10^{6} \mathrm{HEK} 293 \mathrm{~T}$ cells into 6-well plates in DMEM with 10\% FBS.

4. For each $\mathrm{mAb}$, mix $1.5 \mu \mathrm{g}$ heavy chain together with $1.5 \mu \mathrm{g}$ light chain in $125 \mu \mathrm{L}$ DMEM medium. Add $9 \mu \mathrm{L}$ PEI in another tube containing $125 \mu \mathrm{L}$ DMEM medium.

5. Transfer the PEI solution into the tube with plasmids. Incubate the transfection mixture at room temperature for $20 \mathrm{~min}$.

6. Add $750 \mu \mathrm{L}$ of DMEM into each transfection mixture.

7. Aspirate the medium in the plates. Add the transfection mixture to the cells drop by drop. Gently rock the plate to ensure even distribution. Do not swirl.

8. Incubate at $37^{\circ} \mathrm{C}$ for $4-6 \mathrm{~h}$. Then, aspirate the medium, and add $3 \mathrm{~mL}$ culture DMEM. Cultivate for another $48 \mathrm{~h}$ at $37^{\circ} \mathrm{C}$.

9. Mix $10 \mu \mathrm{L}$ of culture supernatant with SDS-PAGE loading buffer. Incubate in boiling water for $5 \mathrm{~min}$. Centrifuge the samples in the tube at $15,000 \times g$ for $1 \mathrm{~min}$.

10. Load the samples onto a precast SDS-PAGE gel (4-10\%), and separate the proteins by electrophoresis.

11. Transfer the proteins onto a nitrocellulose membrane.

12. Perform western blotting to assess the expression of each $\mathrm{mAb}$ using anti-hIgG/HPR (diluted by $1: 1000$ ). As indicated in Fig. 5, two bands (indicating the heavy and light chain, respectively) are observed under reducing conditions (see Note 25).

1. Centrifuge the culture supernatant containing $\mathrm{mAbs}$ at $15,000 \times g$ at $4{ }^{\circ} \mathrm{C}$ for $10 \mathrm{~min}$ to avoid any cell debris. Transfer the supernatant into another $1.5 \mathrm{~mL}$ tube.

2. Insert the Sensor Chip Protein A to the instrument of Biacore T100. Prime with $1 \times$ HBS-EP buffer. Adjust the flow rate to $30 \mu \mathrm{L} / \mathrm{min}$.

3. Load clarified supernatant from the first step in this section onto the Sensor Chip Protein A flow channel (Fc) 2 for $60 \mathrm{~s}$ (the amount of supernatant injected to the sensor is $30 \mu \mathrm{L}$ ). Leave Fcl empty as negative control. Record the response unit (RU).

4. Inject $3 \mathrm{M} \mathrm{MgCl}_{2}$ to both $\mathrm{Fcl}$ and $\mathrm{Fc} 2$ to dissociate the mAb from protein A (regeneration).

5. Calculate the amount of supernatant that is needed to obtain $\sim 500 \mathrm{RU}$ in Fc 2. Dilute the supernatant or extend the 


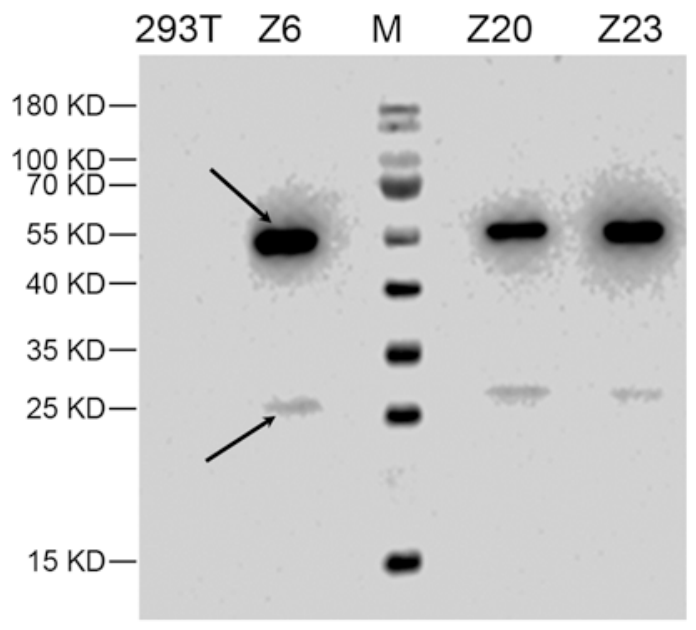

Fig. 5 Western blot to analyze the expression of mAbs. We loaded $10 \mu \mathrm{L}$ of culture supernatant of HEK 239T cells, which were transfected with plasmids containing Ig genes for the indicated mAbs. Then, the goat anti-hlgG antibody conjugated with HRP (1:1000) was used to incubate the membrane transferred with the mAbs. Here, we displayed the results for Z6, Z20, and Z23. The upper arrow indicates the heavy chain, and the lower arrow indicates the light chain. 293T represents the parallel culture supernatant of HEK 293T cells without transfections

injecting time, if necessary ( see Note 28). Then load the supernatant used in step 3 in this section to Fc 2 again.

6. Change the flow path to Fc 1-Fc 2. Then wash the sensor chip with $1 \times$ HBS-EP for $3 \mathrm{~min}$.

7. Inject serially diluted Zika $\mathrm{E}$ protein that has been exchanged into $1 \times$ HBS-EP buffer into the sensor chip in the $\mathrm{Fc} 2-\mathrm{Fc}$ 1 mode. The binding response is recorded (see Note 29).

8. Repeat step 4 for regeneration.

9. Load another mAb supernatant, and test its interaction with Zika $\mathrm{E}$ as in steps 3-7 in this section.

10. Calculate the binding kinetics between Zika E protein and the indicated $\mathrm{mAbs}$, if there are interactions between them, using Biacore T100 evaluation software, version 1.0 ( see Note 30).

11. Thus, using SPR, the true binders and their binding affinities to Zika $\mathrm{E}$ are determined.

\section{Notes}

1. EtBr stains DNA by intercalating between the bases of DNA. It will also intercalate into human DNA, so wear gloves to prevent contact with it. A separate space is also recommended for performing all experiments using EtBr-containing materials. 
2. Do not pull the comb out too soon, as it causes the wells to collapse. It will take 15-20 min to gel. If the gel cannot be used in $1 \mathrm{~h}$, it is recommended to transfer the gel without comb into a tank containing $1 \times$ TAE buffer.

3. The primers used for the amplification of Ig genes are the same as reported (see Tables 2-8) [18]. However, after sequencing, cloning of the expression vectors was designed based on the pCAGGS vector.

4. All primers are stored in small aliquots to avoid repeated freezing and thawing.

5. The blood sample of the convalescent Zika patient was collected 20 days post onset of fever, headache, and dizziness. It is reported that after immunization, antigen-specific B cells with a memory phenotype could be detected in the blood within 1 week [19]. In the presence of antigens, memory B cells undergo affinity maturation, and their B-cell receptors have increased affinities for the antigen. Studies on memory B cells after smallpox vaccination in humans indicated that antigenspecific memory B cells initially declined postimmunization (1 year) but then reached a plateau $\sim$ tenfold lower than peak and were stably maintained for $>50$ years after vaccination [20]. Thus, considering the time that needed for affinity maturation, we recommend collecting the blood 1 month-1 year post onset of symptoms to isolate specific mAbs.

6. When layering the sample, do not mix the density gradient medium solution and the diluted blood sample. Keep them in separate layers.

7. The break should be turned off at this step. For other steps using centrifuging, set the break on.

8 . If the blood has been collected for $>2 \mathrm{~h}$, extend the centrifuging time to $30 \mathrm{~min}$.

9. Usually, 3-4 mL of solutions containing PBMCs will be pipetted out from $10 \mathrm{~mL}$ of the blood.

10. For example, if the cell density is determined to be $1 \times 10^{6} /$ $\mathrm{mL}$ at step 13 in Subheading 3.1, the total cell number is $1 \times$ $10^{6} / \mathrm{mL} \times 15 \mathrm{~mL}=1.5 \times 10^{7}$. Thus, we need to add $1.5 \mathrm{~mL}$ freezing medium to resuspend the cells.

11. Freshly prepared PBMCs exert higher efficiencies for Ig gene amplification than frozen cells. Thus, freshly prepared PBMCs are recommended for the isolation of mAbs. In case the following cell sorting cannot be performed immediately, the methods using the freezing cells are provided in Subheading 3.2 .

12. Memory B cells express CD19 and CD27, but not CD38. In this study, we focus on the $\mathrm{IgG}^{+}$memory B cells. 
13. If fresh PBMCs are used here, please skip to step 8. If using frozen cells, please follow step 2 .

14. Before turning the tube right side up, it is recommended to aspirate the liquid left around the tube orifice.

15. It is difficult to decant the entire buffer. Usually, $\sim 50 \mu \mathrm{L}$ of buffer will be left. Thus, we add $50 \mu \mathrm{L}$ FACS buffer for $10^{7}$ cells or $150 \mu \mathrm{L}$ for $2 \times 10^{7}$ cells.

16. There are three antibodies conjugated with $\mathrm{PE}-\mathrm{Cy}{ }^{\circledR} 5$. They are anti-human $\mathrm{CD} 3 / \mathrm{PE}-\mathrm{Cy}{ }^{\circledR} 5$, anti-human $\mathrm{CDl} 6 / \mathrm{PE}-\mathrm{Cy}^{\circledR} 5$, and anti-human $\mathrm{CD} 235 \mathrm{a} / \mathrm{PE}-\mathrm{Cy}{ }^{\mathbb{B}} 5$. Any of the three are suitable for preparation of the compensation beads for PE-Cy ${ }^{\circledR} 5$.

17. The steps in this section are specific to, but not limited to, a BD FACSAria III cytometer.

18. Here, we use the markers for T cells, NK cells, and platelets for negative selection, to exclude their disturbance.

19. Here, we include FSC-A and FSC-H to exclude cell aggregates.

20. We are not sure about the proportion of memory B cells that bind to Zika E protein. Thus, it is difficult to set the threshold to distinguish antigen-specific memory $\mathrm{B}$ cells from those targeting other antigens in the sample of Zika patient PBMCs. In previous work, we studied the interaction between the receptor-binding domain (RBD) of Middle East respiratory syndrome coronavirus (MERS-CoV) and its receptor CD26, which is widely expressed on lymphocytes, including $\mathrm{T}$ cells. Here, we used the MERS-RBD, which is also tagged at its C-terminus with $6 \times$ His like the Zika E protein, to stain PBMCs from a healthy donor. Then, anti-His/PE was applied to bind to the His tag. Through comparison between the results in Fig. 2B and $\mathrm{C}$, we could determine the threshold to gate the Zika E-specific memory $\mathrm{B}$ cells, as indicated in Fig. 2D.

21. The PCR reactions are performed in 96-well plates.

22. The combined primers are used to amplify Ig genes in the PCRb. However, different primers in a single tube might disturb each other and reduce their annealing efficiency. Thus, in terms of the single cells that yield typical bands for the kappa or lambda chain but not for heavy chain in gel electroporation, we usually repeat PCRb using the separate primers. In addition, $\mathrm{MgCl}_{2}$ exerts effects on the activities of DNA polymerase (for sing-cell PCR). Varied concentrations of $\mathrm{MgCl}_{2}$, ranging from 1.5 to $4.5 \mathrm{mM}$, can also be applied to amplify the variable region of the heavy chain from single cell, whose light chains' variable regions have been sequenced.

23. From PMBCs isolated from $10 \mathrm{~mL}$ whole blood of a convalescent patient, we finally sequenced 15 paired mAbs, which have been published previously [8]. 
24. Here, we introduce the traditional method to double digest the PCR segments with two restriction enzymes and clone them into the same sites in the linearized pCAGGS vector using T4 ligase. However, other methods (e.g., In-Fusion reaction [21]) can be used.

25. Here we displayed the results for Z6, Z20, and Z23.

26. The steps in this section are specific to, but not limited to, a Biacore T100 system.

27. In addition to SPR, enzyme-linked immunosorbent assay is another typical method to assess the interaction between mAbs and antigens. However, for Zika E-specific mAbs, we found that some of them displayed relatively low response to the antigens coated on the plate (data not shown here). It is possible that Zika E proteins undergo some conformational changes when adsorbing to the plate, which results in the decreased binding to certain mAbs. In terms of SPR experiments, the mAbs were captured on the chip through interactions with protein $\mathrm{A}$, which binds to the Fc region. Thus, the CDRs of mAbs orient to the buffer flowing over the chip surface. In addition, the Zika $\mathrm{E}$ proteins in the buffer of HBS-EP are label-free and more prone to be in its native conformation than those coated on the plate. Thus, we chose SPR assay to detect the interaction between mAbs and antigens.

28. For example, if the original supernatant reaches to $1000 \mathrm{RU}$ with $30 \mu \mathrm{L}$, then shorten the injecting time from 60 to $30 \mathrm{~s}$, or dilute the supernatant with equal volume of $1 \times$ HBS-EP buffer and load $60 \mathrm{~s}$. If $30 \mu \mathrm{L}$ of the original supernatant enables $200 \mathrm{RU}$, then extend the injecting time to $150 \mathrm{~s}$.

29. Due to the different binding kinetics between an antigen and its $\mathrm{mAb}$, we set varied dissociation time. For example, mAb Z6 dissociates with Zika $E$ with very low rate; thus we set $600 \mathrm{~s}$ for their dissociation. However, for both Z20 and Z23, they are ready to dissociate with the antigen, and $60 \mathrm{~s}$ was used for their dissociation (Fig. S2 G, J, and L in the paper [8]).

30. Due to the different binding kinetics between $\mathrm{mAbs}$ and Zika $\mathrm{E}$ protein, the data could be fit by either a steady state affinity model or 1:1 (Langmuir) binding model.

\section{Acknowledgments}

This work was supported by the Strategic Priority Research Program of the Chinese Academy of Sciences (grant no. XDB29040201). Q.W. is supported by the Youth Innovation Promotion Association CAS (grant no. 2018119) and National 
Natural Science Foundation (NSFC) of China (grant nos. 81922044 and 81973228 ). J.Y. is supported by the foundation of the NSFC Innovative Research Group (grant no. 81621091).

\section{References}

1. Cao-Lormeau VM, Blake A, Mons $S$ et al (2016) Guillain-Barre Syndrome outbreak associated with Zika virus infection in French Polynesia: a case-control study. Lancet 387:1531-1539

2. Carteaux G, Maquart M, Bedet A et al (2016) Zika virus associated with meningoencephalitis. N Engl J Med 374:1595-1596

3. Mlakar J, Korva M, Tul N et al (2016) Zika virus associated with microcephaly. $\mathrm{N}$ Engl J Med 374:951-958

4. Ventura CV, Maia M, Bravo-Filho V et al (2016) Zika virus in Brazil and macular atrophy in a child with microcephaly. Lancet 387:228

5. Wang Q, Yan J, Gao GF (2017) Monoclonal antibodies against Zika virus: therapeutics and their implications for vaccine design. J Virol 91. https://doi.org/10.1128/JVI.01049-17

6. Wang $S$, Hong $S$, Deng YQ et al (2017) Transfer of convalescent serum to pregnant mice prevents Zika virus infection and microcephaly in offspring. Cell Res 27:158-160

7. Li C, Gao F, Yu L et al (2018) A single injection of human neutralizing antibody protects against Zika virus infection and microcephaly in developing mouse embryos. Cell Rep 23:1424-1434

8. Wang Q, Yang H, Liu X et al (2016) Molecular determinants of human neutralizing antibodies isolated from a patient infected with Zika virus. Sci Transl Med 8:369ral79

9. Robbiani DF, Bozzacco L, Keeffe JR et al (2017) Recurrent potent human neutralizing antibodies to Zika virus in Brazil and Mexico. Cell 169:597-609.e511

10. Stettler K, Beltramello M, Espinosa DA et al (2016) Specificity, cross-reactivity and function of antibodies elicited by Zika virus infection. Science 353:823-826

11. Wu Y, Li S, Du L et al (2017) Neutralization of Zika virus by germline-like human monoclonal antibodies targeting cryptic epitopes on envelope domain III. Emerg Microbes Infect 6:e89
12. Zhao H, Fernandez E, Dowd KA et al (2016) Structural basis of Zika virus-specific antibody protection. Cell 166:1016-1027

13. Tiller T, Meffre E, Yurasov S et al (2008) Efficient generation of monoclonal antibodies from single human B cells by single cell RT-PCR and expression vector cloning. J Immunol Methods 329:112-124

14. Scheid JF, Mouquet $\mathrm{H}$, Feldhahn $\mathrm{N}$ et al (2009) Broad diversity of neutralizing antibodies isolated from memory $B$ cells in HIV-infected individuals. Nature 458:636-640

15. Gilman MS, Castellanos CA, Chen $M$ et al (2016) Rapid profiling of RSV antibody repertoires from the memory $\mathrm{B}$ cells of naturally infected adult donors. Sci Immunol 1. https://doi.org/10.1126/sciimmunol. aaj1879

16. Scherer EM, Smith RA, Simonich CA et al (2014) Characteristics of memory B cells elicited by a highly efficacious HPV vaccine in subjects with no pre-existing immunity. PLoS Pathog 10:e1004461

17. Wang Q, Ma T, Wu Y et al (2019) Neutralization mechanism of human monoclonal antibodies against Rift Valley fever virus. Nat Microbiol 4:1231-1241

18. Liao HX, Levesque MC, Nagel A et al (2009) High-throughput isolation of immunoglobulin genes from single human B cells and expression as monoclonal antibodies. J Virol Methods 158:171-179

19. Blink EJ, Light A, Kallies A et al (2005) Early appearance of germinal center-derived memory $\mathrm{B}$ cells and plasma cells in blood after primary immunization. J Exp Med 201:545-554

20. Crotty S, Felgner P, Davies H et al (2003) Cutting edge: long-term B cell memory in humans after smallpox vaccination. J Immunol 171:4969-4973

21. Park J, Throop AL, LaBaer J (2015) Sitespecific recombinational cloning using gateway and in-fusion cloning schemes. Curr Protoc Mol Biol 110:3.20.21-3.20.23 